\title{
INFLUENCE OF VARYING LEVELS OF RUMEN DEGRADABLE TO UNDEGRADABLE PROTEIN ON MILK YIELD, COMPOSITION AND SOME BLOOD PARAMETERS OF KARADI EWES
}

\author{
Jalal Eliya Alkass \\ Kamal Noman Dosky \\ Emad Tayar Sadeeq Buti \\ School of Animal Production, Faculty of Agriculture and Forestry, University of Duhok, \\ Duhok, Kurdistan Region IRAQ \\ E-mail: nljealkas2001@yahoo.com
}

\begin{abstract}
Twenty-four lactating Karadi ewes, 3-5 years old and 54 $\pm 0.69 \mathrm{~kg}$ in body weight were used to study the effect of rumen degradable protein (RDP) to rumen undegradable protein (RUP) ratio on milk yield, composition and some blood metabolites. Ewes with their lambs were placed in individual pens and fed ad libitum on three rations containing different levels of RDP:RUP namely 68:32 (T1), 56:44 (T2) and 50:50 (T3). Milk yield was recorded in two successive days at biweekly intervals commencing at $2^{\text {nd }}$ week post lambing by using hand milking and lamb suckling technique. Also, blood samples were withdrawn at start, mid and the end of the experimental period ( 84 days).

Daily milk yield and total milk yield averaged $1.16 \pm 0.038$ and $98.31 \pm 4.44 \mathrm{~kg}$, respectively. Feeding ewes protected soybean meal (SBM) resulted in a nonsignificant increase in milk yield in T3 (15.22\%), and $12.06 \%$ in fat corrected milk (FCM) in T2 as compared to control. A significant $(\mathrm{P}<0.05)$ effect of treatment on both percentage and yield of fat and protein was observed. However, the highest fat percent and yield was recorded in T2, whereas, the highest percent and yield of protein was noticed in T2 and T3, respectively. Cholesterol and urea levels was significantly $(\mathrm{P}<0.05)$ lower in $\mathrm{T} 1$ as compared to other groups.
\end{abstract}

Keywords: RDP: RUP ratios, Milk, Blood biochemical, Karadi ewes.

Received: 6/5/2012, Accepted: 17/12/2012.

\section{INTRODUCTION}

In ruminant animal diets, dietary protein is provided in the form RDP and RUP and the requirement of each part especially RDP vary according to physiological state like growth, lactation and pregnancy ( Ali et al, 2009). Sufficient RDP is essential to support the growth of rumen microbes, which may constitute 60 to $75 \%$ of amino acids flow to the small intestine (Anonymous, 1980).

Low RDP levels may compromise microbial growth, dry matter digestibility, and protein availability to the host. However, excess RDP that is not utilized for microbial growth is excreted in feces or deaminated to ammonia and excreted via urine and milk (Castillo et al., 2001).

It is established that the higher the RUP content in diet, may be necessary for optimal performance of the animal (Schingoethe et al., 1988; Broderick et al., 1990) but with inconsistent response (Wattiaux et al., 1994). Also it has been reported that milk yield increased quadartically with increasing dietary undegradable intake protein

\footnotetext{
*Part of M. Sc. Thesis submitted by the third author.
} 
(UIP) resulting in the greatest milk yield with $75 \mathrm{~g} / \mathrm{d}$ of UIP (Toghdory et al., 2009). Similarly, supplementation RUP in the form of expeller soybean meal increased the flow of non-ammonia, non-microbial nitrogen to the small intestine and increased milk production by $10 \%$ (Broderic et al., 2002) in dairy cattle. Moreover, it was concluded that a ratio of 55:45 RDP: RUP in the diet may result in a higher milk production as compared with a ratio of 75:25 in lactating goats (Mishra and Rai, 1996).

The aim of the current work is to study the effect of different ratios of rumen degradable to undegradable protein in isonitrogenous and isocaloric rations in Karadi ewes on feed intake, milk yield and composition, and some blood parameters.

\section{MATERIALS AND METHODS}

Twenty-four lactating Karadi ewes, 3 to 5 years old, and $54 \pm 0.69 \mathrm{~kg}$ in weight were randomly divided into three groups, placed in individual pens $(1.3 \times 1.5 \mathrm{~m})$ with their lambs, and fed on three rations differ in their contents of RDP to RUP through treated SBM by mixing with formaldehyde 6 ltlers of formalin (37\%) with 3 liters of acetic acid, and the mixture was diluted with 45 liters of water, and sprayed over the SBM using electrical mixer. After that the mixture was covered by polyethylene for 48 hrs, and then was sprayed on the floor to disposal the odor and formaldehyde gas for $72 \mathrm{hrs}$ (Table 1). Concentrate was offered ad libitum, twice daily at 8.00 a.m and 6.00 p.m, and refusals were collected and weighted on the next day before the morning feeding. Wheat straw was offered also ad libitum. Clean water was available constantly. Samples of feedstuff were collected after formulation of diet, and were chemically analyzed according to AOAC (Anonymous , 1980) for dry matter, organic matter, ether extract, crude protein and ash.

Milk yield was recorded in two successive days at biweekly intervals starting from the $2^{\text {nd }}$ week post lambing. The lambs were separated from their mothers at 9.00 p.m., and ewes were hand milked at 9.00 a.m., in the following morning. Then the lambs were weighed and allowed to suckle their mothers for about 15 minutes and were weighed again to find out the amount of milk suckled. The daily milk yield was calculated by summing up the milk obtained by hand and milk suckled and multiplied the result by 2 .

Milk samples $(50 \mathrm{ml})$ were collected at biweekly intervals and immediately were analyzed by Ekomilk total (Eon Trading LLC, U.S.A) to determine the chemical composition of the milk.

Blood samples $(10 \mathrm{ml})$ were collected via jagular vein at 9.00 a.m in the morning before feeding at the start, mid and at the end of lactation. Blood samples centrifuged at $(3500 \mathrm{rpm})$ and frozen for later analysis. Serum samples were analyzed for total protein, albumin, globulin, glucose, cholesterol, triglycerides and urea using analytically kits.

Data were analyzed statistically using GLM procedure of theSAS, (2002), taking into account the effect of treatment, period and their interaction assuming the following model:

$$
\mathbf{Y}_{\mathrm{ijk}}=\boldsymbol{\mu}+\mathbf{T}_{\mathrm{i}}+\mathbf{P}_{\mathrm{j}}+\mathbf{T P}(\mathrm{ij})+\mathbf{e}_{\mathrm{ijk}}
$$

Where: 
$\mathrm{Y}_{\mathrm{ijk}}=$ Observational value of $\mathrm{K}^{\mathrm{th}}$ animal,

$\mu \quad=$ Overall mean,

$\mathrm{T}_{\mathrm{i}}=$ Effect of $\mathrm{i}^{\text {th }}$ treatment $(\mathrm{i}=$ treated, non treated $)$

$\mathrm{P}_{\mathrm{j}} \quad=$ Effect of $\mathrm{j}^{\text {th }}$ lactation Period $(\mathrm{j}=1,2,3,4,5$ and 6$)$.

$\mathrm{TP}_{(\mathrm{ij})}=$ Effect of interaction between ${ }_{\mathrm{i}}{ }^{\text {th }}$ treatment and ${ }_{\mathrm{j}}$ th Period of lactation

$\mathrm{e}_{\mathrm{ijk}}=$ Random error associated with each observation assumed to be NID with $\left(0, \sigma^{2} \mathrm{e}\right)$

Also, the same model was used to study the effects of treatment only on milk yield and feed intake. Duncan multiple test (1955) within SAS (Anonymous , 2002) was used to detect differences among least square means within each factor.

Table (1): Ingredients and chemical composition of the experimental diets.

\begin{tabular}{|l|c|c|c|}
\hline \multirow{2}{*}{ Ingredient \% } & \multicolumn{3}{c|}{ Level of RDP : RUP } \\
\cline { 2 - 4 } & T1 & T2 & T3 \\
\cline { 2 - 4 } & $68: 32$ & $56: 44$ & $50: 50$ \\
\hline White barley & 40 & 40 & 39 \\
\hline Wheat bran & 21 & 21 & 15 \\
\hline Corn & 25 & 25 & 26.5 \\
\hline Untreated soy bean meal & 12 & ---- & ---- \\
\hline Formaldehyde treated SBM & ---- & 12 & 18 \\
\hline Urea & 0.5 & 0.5 & ---- \\
\hline Salt & 0.5 & 0.5 & 0.5 \\
\hline Limestone & 0.5 & 0.5 & 0.5 \\
\hline Vitamins & 0.5 & 0.5 & 0.5 \\
\hline \multicolumn{2}{|c|}{ Chemical composition } & & \\
\hline Dry Matter * & 93.24 & 93.59 & 93.25 \\
\hline Organic Matter * & 88.35 & 88.64 & 88.32 \\
\hline Ether Extract* & 2.55 & 2.21 & 2.63 \\
\hline Crud Protein \% $*$ & 14.3 & 14.3 & 14.2 \\
\hline Ash\% * & 4.89 & 4.95 & 4.93 \\
\hline Metabolic Energy $(\mathrm{ME}) \mathrm{MJ} / \mathrm{kg} * *$ & 11.15 & 11.15 & 11.17 \\
\hline
\end{tabular}

* Chemical analysis was carried out (on the basis of dry matter) at the nutrition lab. School of Animal Production. $\quad * *$ Calculated according to AlKhawaja et al. (1978).

\section{RESULTS AND DISCUSSION}

Daily Nutrient Intake: In this study, results in Table (2) showed no significant effect of rumen degradable to undegradable protein ratios on DM, OM, CP and ME intake. This result agree with the finding of Firkins, et. al., 1986 who noted that supplementation of RUP did not affect DMI using plant CP sources. Braud (2005) demonstrated that feeding low RDP to non lactating cows resulted in no appreciable impact on feed intake or apparent diet digestibility. On other hand Hassan and Bryant (1986) showed that the supplemental RUP increases feed intake and body growth rate of sheep . 
Table (2): Effect of RDP: RUP on DMI, OMI, CPI, MEI (MJ), RDPI and RUPI of rations.

\begin{tabular}{|c|c|c|c|c|}
\hline \multirow{2}{*}{ Treatments } & \multicolumn{3}{|c|}{ RDP: RUP } & Significant \\
\cline { 2 - 5 } & T1 & T2 & T3 & NS \\
\hline DMI $(\mathrm{gm} / \mathrm{d})$ & $1694.45 \pm 5.76$ & $1699.78 \pm 3.55$ & $1696.35 \pm 7.24$ & NS \\
\hline OMI $(\mathrm{gm} / \mathrm{d})$ & $1605.59 \pm 5.46$ & $1609.88 \pm 3.37$ & $1604.58 \pm 6.29$ & NS \\
\hline CPI $(\mathrm{gm} / \mathrm{d})$ & $242.76 \pm 0.82$ & $243.35 \pm 0.51$ & $242.56 \pm 1.03$ & NS \\
\hline MEI $(\mathrm{MJ}) / \mathrm{d}$ & $18.89 \pm 0.06$ & $18.95 \pm 0.04$ & $18.94 \pm 0.08$ & \\
\hline
\end{tabular}

NS not significant, $* * p<0.01$, Means with different letters within grouping differ significantly.

Milk yield and Composition: In the current work, the overall mean of the daily milk yield (DMY) during pre-weaning period (84 days) averaged $1.16 \pm 0.038 \mathrm{~kg}$ (Table 6), and consequently the total milk yield averaged $98.31 \pm 4.44 \mathrm{~kg}$. DMY produced by Karadi ewes was almost similar to those reported earlier by other workers on the same breed. According to Dosky (2007), Baker et al. (2009) and Kassem et al. (2009), DMY was $1.174,1.223$ and $1.097 \mathrm{~kg}$ during 90 days, respectively.

It appear from Table (3) that there is a significant $(p<0.01)$ effect of period of lactation on DMY and FCM. Yet, the highest DMY $(1.51 \mathrm{~kg})$ and FCM $(1.54 \mathrm{~kg})$ were attained during the $3^{\text {rd }}$ period of lactation and decreased gradually toward the lowest value of DMY $(0.74 \mathrm{~kg})$ and FCM $(0.78 \mathrm{~kg})$ at the final period. Also, Fuertes et al. (1998), and Baker et al. (2009) found that the period of lactation had a highly significant effect on the variation in milk yield.

The protection of SBM with formaldehyde treatment lead to a non-significant $(p<0.05)$ increase in T3 $(15.22 \%)$, and $12.06 \%$ in fat corrected milk yield in T2 as compared to $\mathrm{T} 1$. This result could be due to an increase in metabolizable protein availability, which may cause such increase in milk yield of T3 treatment. Similarly, Hadjipanayiotou and Morand-Fehr $(1991)$ showed a 9\% increase $(p<0.05)$ in FCM yield of Damascus goats fed protected SBM. On the other hand this response is lower than 27\% increase in FCM yield reported by Chowdhury et al., (2002) working on German Fawn goats. However, dietary inclusion of formaldehyde treated SBM had no effect on milk yield in dairy cows (Small and Gordon, 1985) and goats (Brun-Bellut et al., 1990). The results presented in Table (3), showed that treatments had a significant $(\mathrm{P}<0.05)$ effect on both percent and yield of milk protein. While the highest percent of protein $(6.58 \pm 0.11 \%)$ was observed in $\mathrm{T} 2$. On the other hand, the highest yield $(80.58 \mathrm{gm} / \mathrm{d})$ of protein was recorded in T3. According to Crawford and Hoover (1984), increased milk protein concentration in cows fed formaldehyde treated meals was usually a result of greater bypass of protein due to formaldehyde treatment, which would increase AA availability at the intestine level. Similarly, Robinson (2004) indicated that the increase in RUP in the ration of dairy cows resulted in a significant increase in milk protein. The results given in Tablae (3) revealed that treatments had a highly significant $(P<0.01)$ effect on both percentage and yield of fat. The highest percent $(5.18 \pm 0.14 \%)$ and yield $(56.74 \pm 2.93 \mathrm{gm} / \mathrm{d})$ was recorded for T2, as compared to the T1. Similarly, other workers noted that protected SBM increased 
the fat percentage of German Fawn goats (Chowdhury et al., 2002), Awassi ewes (ALMaula , 2004) and cows (Ashes et al., 1992). It seems that neither lactose percent nor yield was affected significantly by dietary treatments. Similarly, Dosky (2007) indicated that rations treated with formaldehyde had no significant effect on lactose content of milk in Karadi ewes.

Blood Parameters: In the current work, neither total protein nor their fraction of globulin and albumin was significantly by feeding Karadi ewes different level of RDO:RUP. Similarly, Shamoon et al. (2009), Ali et al. (2005) and Salih (2009) noticed that treated rations with formaldehyde had no significant effect on these parameters. Also, no significant differences in blood glucose concentration among different treatments was exist. The low concentration of glucose in the present experiment could be due to depletion of glucose for lactose synthesis in the mammary gland (Sunbel et al., 1994). Similarly, Kassem et al. (2009) and Shamoon et al. (2009) showed that the ration treated with formaldehyde had no effect on serum blood glucose in Karadi and Awassi ewes, respectively. Al-Mallah (2007) noted that feed formaldehyde treated ration had no significant effect in triglyceride concentration. The average serum cholesterol concentrations were $51.39 \pm, 60.41 \pm$ and $59.00 \pm \mathrm{mg} / 100 \mathrm{ml}$ for T1, T2 and T3, respectively which are within the normal range of $52-76 \mathrm{mg} / 100 \mathrm{ml}$ as indicated by Kaneko et al. (1997). Cholesterol level was significantly $(\mathrm{p}<0.05)$ lower $(51.39 \pm 2.75)$ in T1 compared to both T2 But T1 showed a significant lower

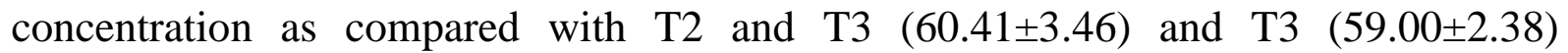
(Table 4).

The reason for this may be in part due to the protection of fat from microbial degradation which may lead to increase rumen fat bypass which hydrolyzed and absorbed in the intestine (Shamoon et al., 2009). Similarly, it was reported that cholesterol of serum has been increased consistently in response to the feeding of protected polyunsaturated fat with a variety of formaldehyde protected feedstuff (Bitman et al., 1974; Wren et al., 1975). Serum triglyceride averaged 62.35, 58.01 and $59.03 \mathrm{mg} / 100 \mathrm{ml}$ for T1, T2 and T3 respectively (Table 4) which are within the normal range of triglyceride in sheep (54-76 mg/100ml) as indicated by Hayrattin (2005). The level of triglyceride did not differ significantly among different treatments. These results resemble those of Al-Mallah (2007) who noticed that the effect of the treated rations with formaldehyde had no effect on the levelof triglyceride in Awassi ewes. Urea concentration was decreased significantly $(\mathrm{p}<0.05)$ in $\mathrm{T} 1 \quad(41.46 \mathrm{mg} / \mathrm{dl})$ as compared to T2 (48.96 mg/dl) and T3 (49.63 mg/dl), although the differences was significant but values were in the normal range $(27 .-64 \mathrm{mg} / \mathrm{dl})$ reported by Hayrettin (2005). Such difference among treatments could be attributed to the differences in RDP in the rations (Kassem et al., 2009). Similarly, Al-Dabagh (2010) found a higher urea concentration in ewes fed diets treated with formaldehyde. It can be concluded that feeding protected soybean meal improve milk, fat and protein yield of Karadi sheep. 
Table (3): Effect of RDP: RUP ratio and lactating period on milk yield and composition in Karadi ewes (Means and S.E.)

\begin{tabular}{|c|c|c|c|c|c|c|c|c|c|}
\hline & $\begin{array}{c}\text { TMY } \\
(\mathrm{kg})\end{array}$ & DMY (kg/d) & $\begin{array}{c}\mathrm{FCM}(4 \%) \\
\mathrm{kg} / \mathrm{d}\end{array}$ & Protein $\%$ & $\begin{array}{c}\text { Protein } \\
\text { Yield gm/d }\end{array}$ & Fat $\%$ & $\begin{array}{c}\text { Fat Yield } \\
\mathrm{gm} / \mathrm{d}\end{array}$ & Lactose \% & $\begin{array}{c}\text { Lactose } \\
\text { Yield gm/d }\end{array}$ \\
\hline Overall all mean & $\begin{array}{c}98.31 \pm \\
4.44 \\
\end{array}$ & $\begin{array}{c}1.16 \pm \\
0.03\end{array}$ & $\begin{array}{c}1.22 \pm \\
0.40\end{array}$ & $\begin{array}{c}6.36 \pm \\
0.06 \\
\end{array}$ & $\begin{array}{c}73.87 \pm \\
2.51 \\
\end{array}$ & $\begin{array}{c}4.43 \pm \\
0.09\end{array}$ & $\begin{array}{c}50.73 \pm \\
1.78 \\
\end{array}$ & $\begin{array}{c}4.60 \pm \\
0.02\end{array}$ & $\begin{array}{c}53.45 \pm \\
1.756 \\
\end{array}$ \\
\hline \multicolumn{10}{|c|}{ Treatment } \\
\hline 1 & $\begin{array}{c}94.28 \pm \\
7.22\end{array}$ & $\begin{array}{c}1.12 \pm \\
0.06\end{array}$ & $\begin{array}{c}1.16 \pm \\
0.68\end{array}$ & $\begin{array}{l}6.19 \pm \\
0.09 b\end{array}$ & $\begin{array}{c}69.08 \pm \\
3.86 \mathrm{~b}\end{array}$ & $\begin{array}{l}4.26 \pm \\
0.14 b\end{array}$ & $\begin{array}{c}47.49 \pm \\
3.02 \mathrm{~b}\end{array}$ & $\begin{array}{c}4.56 \pm \\
0.02\end{array}$ & $\begin{array}{c}51.12 \pm \\
2.854\end{array}$ \\
\hline 2 & $\begin{array}{c}93.33 \pm \\
6.29\end{array}$ & $\begin{array}{l}1.13 \pm \\
0.06\end{array}$ & $\begin{array}{l}1.30 \pm \\
0.64\end{array}$ & $\begin{array}{l}6.58 \pm \\
0.11 \mathrm{a}\end{array}$ & $\begin{array}{l}72.38 \pm \\
3.63 \mathrm{ab}\end{array}$ & $\begin{array}{l}5.18 \pm \\
0.14 \mathrm{a}\end{array}$ & $\begin{array}{c}56.74 \pm \\
2.93 \mathrm{a} \\
\end{array}$ & $\begin{array}{c}4.63 \pm \\
0.01\end{array}$ & $\begin{array}{c}51.29 \pm \\
2.532 \\
\end{array}$ \\
\hline 3 & $\begin{array}{c}108.63 \pm \\
9.49 \\
\end{array}$ & $\begin{array}{l}1.25 \pm \\
0.07 \\
\end{array}$ & $\begin{array}{c}1.22 \pm \\
0.76\end{array}$ & $\begin{array}{l}6.32 \pm \\
0.10 \mathrm{ab} \\
\end{array}$ & $\begin{array}{c}80.58 \pm \\
5.41 \mathrm{a} \\
\end{array}$ & $\begin{array}{l}3.81 \pm \\
0.08 \mathrm{c} \\
\end{array}$ & $\begin{array}{c}47.77 \pm \\
3.19 \mathrm{~b} \\
\end{array}$ & $\begin{array}{c}4.63 \pm \\
0.05 \\
\end{array}$ & $\begin{array}{c}58.24 \pm \\
3.660 \\
\end{array}$ \\
\hline \multicolumn{10}{|c|}{ Period } \\
\hline 1 & - & $\begin{array}{c}1.28 \pm \\
0.06 \mathrm{ab} \\
\end{array}$ & $\begin{array}{l}1.38 \pm \\
0.75 \mathrm{a} \\
\end{array}$ & $\begin{array}{c}6.08 \pm \\
0.08 \mathrm{bc} \\
\end{array}$ & $\begin{array}{c}78.31 \pm \\
3.87 \mathrm{~b}\end{array}$ & $\begin{array}{c}4.44 \pm \\
0.17 \\
\end{array}$ & $57.01 \pm 3.449 a$ & $\begin{array}{c}4.56 \pm \\
0.01 \\
\end{array}$ & $\begin{array}{c}58.79 \pm \\
2.94 \mathrm{a} \\
\end{array}$ \\
\hline 2 & - & $\begin{array}{l}1.35 \pm \\
0.07 \mathrm{ab}\end{array}$ & $\begin{array}{l}1.43 \pm \\
0.87 \mathrm{a}\end{array}$ & $\begin{array}{l}6.01 \pm \\
0.17 \mathrm{c} \\
\end{array}$ & $\begin{array}{c}81.55 \pm \\
5.22 \mathrm{~b}\end{array}$ & $\begin{array}{c}4.44 \pm \\
0.21\end{array}$ & $59.81 \pm 4.136 a$ & $\begin{array}{c}.64 \pm \\
0.09\end{array}$ & $\begin{array}{c}63.02 \pm \\
3.87 \mathrm{a} \\
\end{array}$ \\
\hline 3 & - & $\begin{array}{l}1.51 \pm \\
0.09 \mathrm{a}\end{array}$ & $\begin{array}{l}1.54 \pm \\
0.88 \mathrm{a}\end{array}$ & $\begin{array}{l}6.58 \pm \\
0.09 \mathrm{a}\end{array}$ & $\begin{array}{c}97.08 \pm \\
6.45 \mathrm{a}\end{array}$ & $\begin{array}{c}4.38 \pm \\
0.23\end{array}$ & $62.83 \pm 4.13 \mathrm{a}$ & $\begin{array}{c}4.61 \pm \\
0.01\end{array}$ & $\begin{array}{c}67.40 \pm \\
4.06 \mathrm{a}\end{array}$ \\
\hline 4 & - & $\begin{array}{l}1.26 \pm \\
0.09 \mathrm{~b}\end{array}$ & $\begin{array}{l}1.32 \pm \\
1.05 \mathrm{a} \\
\end{array}$ & $\begin{array}{l}6.56 \pm \\
0.14 \mathrm{a} \\
\end{array}$ & $\begin{array}{l}83.24 \pm \\
6.61 \mathrm{ab} \\
\end{array}$ & $\begin{array}{c}4.39 \pm \\
0.22 \\
\end{array}$ & $54.76 \pm 4.741 b$ & $\begin{array}{c}4.58 \pm \\
0.03 \\
\end{array}$ & $\begin{array}{c}57.99 \pm \\
4.57 \mathrm{a} \\
\end{array}$ \\
\hline 5 & - & $0.829 \pm 0.05 c$ & $\begin{array}{l}0.87 \pm \\
0.63 b\end{array}$ & $\begin{array}{c}6.41 \pm \\
0.16 \mathrm{ab}\end{array}$ & $\begin{array}{c}52.92 \pm \\
4.21 \mathrm{c} \\
\end{array}$ & $\begin{array}{c}4.50 \pm \\
0.25\end{array}$ & $36.34 \pm 2.93 b$ & $\begin{array}{c}4.62 \pm \\
0.01\end{array}$ & $\begin{array}{l}38.00 \pm \\
2.70 \mathrm{~b} \\
\end{array}$ \\
\hline 6 & - & $0.743 \pm 0.04 \mathrm{c}$ & $\begin{array}{l}0.78 \pm \\
0.48 \mathrm{~b}\end{array}$ & $\begin{array}{l}6.54 \pm \\
0.16 \mathrm{a}\end{array}$ & $\begin{array}{c}48.61 \pm \\
3.35 \mathrm{c}\end{array}$ & $\begin{array}{c}4.43 \pm \\
0.23\end{array}$ & $32.44 \pm 2.23 b$ & $\begin{array}{c}4.61 \pm \\
0.02\end{array}$ & $\begin{array}{c}34.25 \pm \\
2.17 \mathrm{~b}\end{array}$ \\
\hline
\end{tabular}

Means with different letters with grouping differ significantly $(\mathrm{p}<0.01)$. 
Table (4): Means and S.E. for effect of RDP: RUP and period of blood collection on blood parameters.

\begin{tabular}{|c|c|c|c|c|c|c|c|}
\hline & $\begin{array}{c}\text { Total protein } \\
\mathrm{gm} / 100 \mathrm{ml}\end{array}$ & $\begin{array}{l}\text { Albumin } \\
\mathrm{gm} / 100 \mathrm{ml}\end{array}$ & $\begin{array}{l}\text { Globulin } \\
\text { gm/100ml }\end{array}$ & $\begin{array}{c}\text { Glucose } \\
\mathrm{mg} / 100 \mathrm{ml}\end{array}$ & $\begin{array}{c}\text { Cholesterol } \\
\mathrm{mg} / 100 \mathrm{ml}\end{array}$ & $\begin{array}{c}\text { Triglyceride } \\
\mathrm{gm} / 100 \mathrm{ml}\end{array}$ & $\begin{array}{c}\text { Urea } \\
\mathrm{mg} / 100 \mathrm{ml}\end{array}$ \\
\hline $\begin{array}{c}\text { Overall all } \\
\text { mean }\end{array}$ & $\begin{array}{c}6.46 \pm \\
0.10\end{array}$ & $\begin{array}{c}2.88 \pm \\
0.09 \\
\end{array}$ & $\begin{array}{c}3.58 \pm \\
0.11 \\
\end{array}$ & $\begin{array}{c}68.49 \pm \\
1.08 \\
\end{array}$ & $\begin{array}{c}56.90 \pm \\
1.72 \\
\end{array}$ & $\begin{array}{c}59.81 \pm \\
1.17 \\
\end{array}$ & $\begin{array}{c}46.70 \pm \\
1.37 \\
\end{array}$ \\
\hline \multicolumn{8}{|c|}{ Treatment } \\
\hline 1 & $\begin{array}{l}6.34 \pm \\
0.17 \mathrm{a}\end{array}$ & $\begin{array}{l}2.95 \pm \\
0.18 \mathrm{a}\end{array}$ & $\begin{array}{l}3.40 \pm \\
0.18 \mathrm{a}\end{array}$ & $\begin{array}{c}68.62 \pm \\
1.61 \mathrm{a} \\
\end{array}$ & $\begin{array}{l}51.39 \pm \\
2.75 \mathrm{~b}\end{array}$ & $\begin{array}{c}62.35 \pm \\
1.97 \mathrm{a} \\
\end{array}$ & $\begin{array}{l}41.64 \pm \\
2.19 \mathrm{~b} \\
\end{array}$ \\
\hline 2 & $\begin{array}{l}6.67 \pm \\
0.16 \mathrm{a} \\
\end{array}$ & $\begin{array}{l}2.85 \pm \\
0.16 \mathrm{a} \\
\end{array}$ & $\begin{array}{l}3.82 \pm \\
0.16 \mathrm{a} \\
\end{array}$ & $\begin{array}{c}68.43 \pm \\
2.06 \mathrm{a} \\
\end{array}$ & $\begin{array}{c}60.41 \pm \\
3.46 \mathrm{a} \\
\end{array}$ & $\begin{array}{c}58.01 \pm \\
1.91 \mathrm{a} \\
\end{array}$ & $\begin{array}{c}48.96 \pm \\
2.62 \mathrm{a} \\
\end{array}$ \\
\hline 3 & $\begin{array}{l}6.36 \pm \\
0.18 \mathrm{a}\end{array}$ & $\begin{array}{l}2.84 \pm \\
0.12 \mathrm{a}\end{array}$ & $\begin{array}{l}3.52 \pm \\
0.22 \mathrm{a}\end{array}$ & $\begin{array}{c}68.41 \pm \\
2.03 \mathrm{a} \\
\end{array}$ & $\begin{array}{c}59.00 \pm \\
2.38 \mathrm{a} \\
\end{array}$ & $\begin{array}{l}59.03 \pm \\
2.21 \mathrm{a}\end{array}$ & $\begin{array}{c}49.63 \pm \\
2.01 \mathrm{a}\end{array}$ \\
\hline \multicolumn{8}{|c|}{ Period } \\
\hline 1 & $\begin{array}{l}6.36 \pm \\
0.14 b\end{array}$ & $\begin{array}{l}2.80 \pm \\
0.20 \mathrm{~b}\end{array}$ & $\begin{array}{l}3.56 \pm \\
0.15 \mathrm{a}\end{array}$ & $\begin{array}{c}68.06 \pm \\
1.72 \mathrm{a} \\
\end{array}$ & $\begin{array}{l}49.29 \pm \\
2.11 \mathrm{c}\end{array}$ & $\begin{array}{c}61.24 \pm \\
1.82 \mathrm{a}\end{array}$ & $\begin{array}{c}45.43 \pm \\
2.79 \mathrm{a} \\
\end{array}$ \\
\hline 2 & $\begin{array}{l}7.01 \pm \\
0.19 \mathrm{a}\end{array}$ & $\begin{array}{l}3.42 \pm \\
0.14 \mathrm{a}\end{array}$ & $\begin{array}{l}3.59 \pm \\
0.20 \mathrm{a} \\
\end{array}$ & $\begin{array}{c}66.68 \pm \\
2.20 \mathrm{a} \\
\end{array}$ & $\begin{array}{l}56.99 \pm \\
3.20 \mathrm{~b} \\
\end{array}$ & $\begin{array}{c}61.62 \pm \\
1.75 \mathrm{a} \\
\end{array}$ & $\begin{array}{c}47.61 \pm \\
2.59 \mathrm{a} \\
\end{array}$ \\
\hline 3 & $\begin{array}{l}5.99 \pm \\
0.10 \mathrm{~b} \\
\end{array}$ & $\begin{array}{l}2.87 \pm \\
0.10 \mathrm{~b} \\
\end{array}$ & $\begin{array}{l}3.12 \pm \\
0.13 \mathrm{~b} \\
\end{array}$ & $\begin{array}{c}70.83 \pm \\
1.63 \mathrm{a} \\
\end{array}$ & $\begin{array}{c}64.77 \pm \\
2.76 \mathrm{a} \\
\end{array}$ & $\begin{array}{c}56.42 \pm \\
2.42 \mathrm{a} \\
\end{array}$ & $\begin{array}{c}47.08 \pm \\
1.64 \mathrm{a} \\
\end{array}$ \\
\hline
\end{tabular}

Means with different letters with grouping differ significantly $(\mathrm{p}<0.01)$. 


\title{
تأثثير مستويات مختلفة من البروتين التحلل الى غبر التحلل في انتاج الحليب ومكوناته وبعض صفات الام

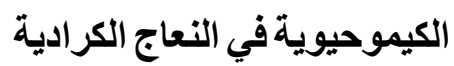

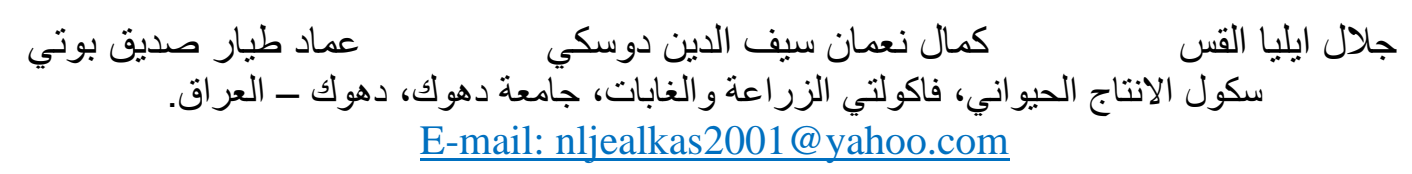

\begin{abstract}
الخلاصة

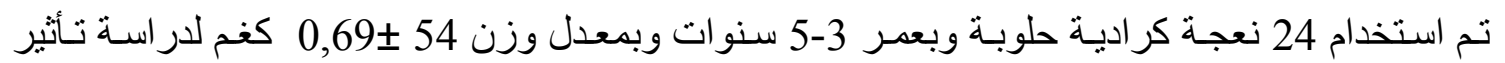

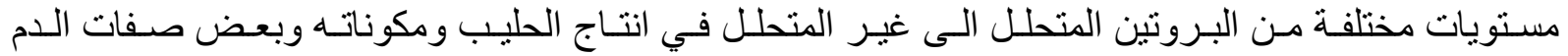

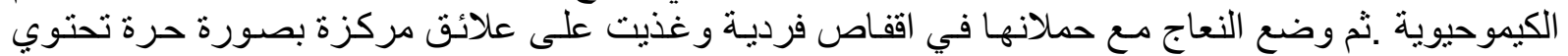

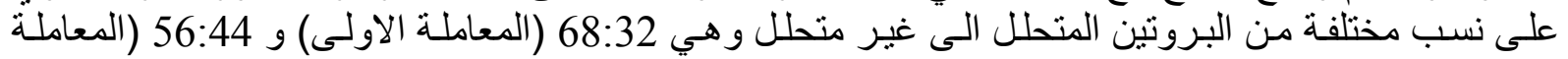

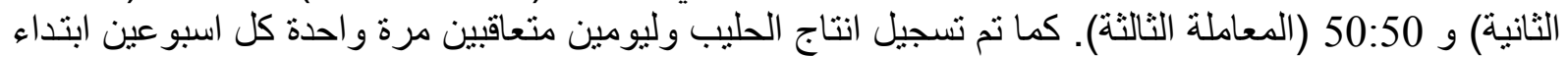

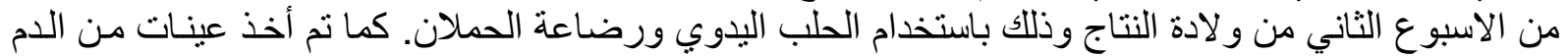

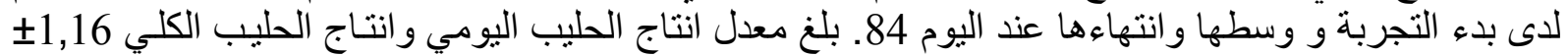

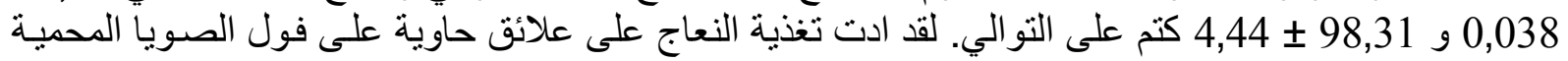

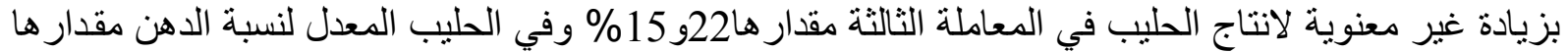

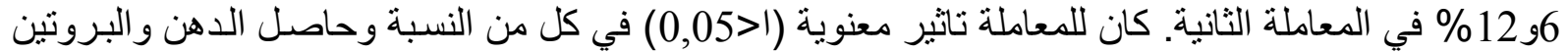

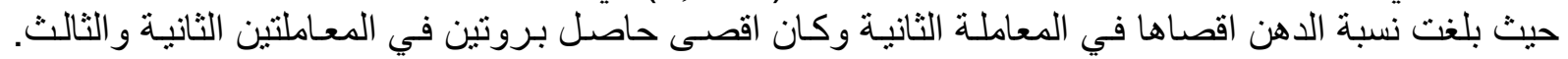

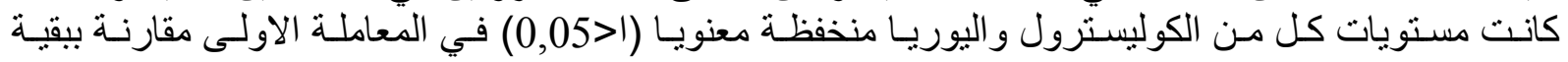

المعاملات.

الكلمات الدالة: RDP، نسبة RUP، الحليب، كيمباء حيوية الدم، نعاج عو اسيه.
\end{abstract}

تاريخ تسلم البحث: 2012/5/6 ، وقبوله: 2012/12/17.

\section{REFERENCES}

Al-Dabagh, R. H. A. (2010). Effect of Urea Supplementation Formaldehyde Treated Rations on Productive Performance and Lambs Growth of Awassi Ewes. M. Sc. Thesis, College of Agriculture and Forestry, University of Mosul.

Ali, C.S.; I. Din; M. Sharif; M. Nisa; A. Javaid; N. Hashmi; M. Sarwar (2009). Supplementation of ruminally protected proteins and amino acids: feed consumption, digestion and performance of cattle and sheep. International Journal of Agriculture and Bioogy. 11: 477-482.

Ali, M. F.; B. E. El-Saidy; M. K. Mohsen; M. M. E. Khalafalla (2005). Performance of lambs fed on ration containing soybean meal treated with formaldehyde and probiotics. ii. Productive and reproductive performance. Egyption Journal Nutrition Feed. 8(1): 511-527.

AL-Khawaja, A. K.; S. A. Matti; R. F. Asadi; K. M. Moktar; S. H. Aboona (1978). The Composition and Nutritive Value of Iraqi Feedstuffs. Nutrition Division publication, Ministry of Agriculture, IRAQ.

Al-Maula, H. A. S. (2004). Effect of Feeding Ration Treated With Formaldehyde on Milk Production and Composition and Lamb Growth. M. Sc. Thesis, College of Agriculture and Forestry, University of Mosul.

Anonymous (2002). User Guide for Personal Computers. Release 6.12 SAS. Institute Inc., Cary, NC. U.S.A. 
Anonymous (2001). Nutrient Requirements of Dairy Cattle. 7th Rev. ed. Natl. Acad. Sci., Washington, DC.

Anonymous (1980). Official Methods of Analysis (13 ${ }^{\text {th }}$ Ed.). Association of Official Analytical Chemists, Washington, DC.

Anonymous (1955). Multiple range and multiple "F" tests. Biometrics. 11: 1-12.

Ashes, J. R.; P. S. T. Vincent Welch; S. K. Gulati; T. W. Scott; G. H. Brown (1992). Manipulation of the fatty acid composition of milk by feeding protected canola seeds. Journal of Dairy Science. 75:1090-1096.

Baker, I. A.; K. N. S. Dosky; J. E. Alkass (2009). Milk yield and composition of Karadi ewes with the special reference to the method of evacuation. Journal of Duhok University. 12: 210-215.

Bitman, J.; T. R. Wren; L. P. Dryden; L. F. Edmondson; R, A. Yoncoskie (1974). Encapsulated vegetable fats in cattle feeds. In Microencapsulation: Processes and Applications. (J, E. Vengdager, ed.) Pp. 57 Plenum Pub. Crop., New York.

Broderick, G. A.; D. R. Mertens; R. Simons (2002). Efficacy of carbohydrate sources for milk production by cows fed diets based on alfalfa silage. Journal of Dairy Science 85:1767-1776.

Broderick, G. A.; D. B. Ricker; L. S. driver (1990). Expeller soybean meal and corn byproducts versus solvent soybean meal for lactating dairy cows fed alfalfa silage as the sole silage. Journal of Dairy Science. 73:453-462.

Braud, T.W. (2005). Effects of Protein Sources With Differing Ruminal degradation

$\mathrm{C}$ on nutrient Digestibilities and Flows through Various Segments

of the Gastrointestinal Tract of Nonlactating Holstein Cows. MSc. Thesis,

Louisiana State University.

Brun-Bellut, J.; G. Blanchart; B. Vignon (1990). Effect of Rumen-degradable protein concentration in diets in digestion, nitrogen utilization and milk yield by dairy goats. Small Ruminant Research 3: 575-581.

Castillo, A. R.; E. Kabreab; D. E. Beever; J. H. Barbi; J. D. Sutton; H. C. Kirby; J. France (2001). The effect of protein supplementation on nitrogen utilization in lactating dairy cows fed grass silage diet. Journal of Animal Science. 79:247253.

Chowdhury, S. A.; H. Rexroth; C. Kijora; K. J. Peters (2002). Lactation performance of German Fawn goats in relation to feeding level and dietary protein protection. Asian-Aus. Journal of Animal Science. 15: 222-237.

Crawford, R. J. Jr.; W. H. Hoover (1984). Effects of particle size and formaldehyde treatment of soybean meal on milk production and composition for dairy cows. Journal of Dairy Science. 67:1945-1952.

Dosky, K. N. S. (2007). Effect of Formaldehyde Treated Concentrate on Production Performance and Some Blood Biochemical Parameters in Karadi Sheep. Ph. D. Thesis, College of Agric. \& Forestry. University of Mosul. 
Firkins, J.L.; L.L. Berger; N.E. Merchen; G.C., IR. Fahey (1986). Effects of feed intake and protein degradability on ruminal characteristics and site of digestion in steers Journal of Dairy Science. 69: 2111-2123.

Fuertes, J. A.; C. Gonzalo; J. A. Carriedo; F. San Primitivo (1998). Parameters of test day milk yield and milk components for dairy ewes. Journal of Dairy Science. 81: 1300-1307.

Hadjipanayiotou, M.; P. Morand-Fehr (1991). Intensive Feeding of Dairy Goats. In: Goat Nutrition. (Ed. P. Morand-Fehr). Pudoc, Wageningen. Pp. 197-208.

Hassan, S.A. ; M.J. Bryant (1986). The response of store lambs to dietary supplements of fish meal. Journal of Animal Production. 42: 233-240.

Hayrettin, C. (2005). Investigation of antioxidant enzymes and some biochemical parameters in ewes with gangrenous mastitis. Turk Journal of Veternary Animal Science. 29: 303-308

Kaneko, J. J.; J. W. Harvey; M. L. Bruss (1997). Clinical Biochemistry of Domestic Animals. Academic Press, USA.

Kassem, M. M.; K. N. S. Dosky; A. Abd El-Ghany (2009). The effect of using reduce ruminal degradability concentrated ration on milk secretion and some biochemical blood measurements in Karadi ewes under pasture condition. Egyptian Journal of Nutrition and feeds. 12 (3): 337-348.

Mishra, S.; S. N. Rai (1996). Effects of different RDP and UDP ratios on voluntary intake, milk production and feed conversion efficiency in lactating goats. Small Ruminant Research. 20:31-38.

Robinson, P. H. (2004). Manipulation of Milk Protein Percentage and Production in Lactating Dairy Cows. Cooperetive Extension, Davis, California.

Salih, M. N. (2009). Effect of Using Reduce Degradability Fodder on Reproductive Performance and Productive Performance of Super Awassi Sheep. Ph. D. Thesis, College of Agriculture and Forestry, University of Mosul.

Schingoethe, D. J.; D. P. Casper; C. Yang; D. G. Illg; J. L. Sommerfeldt; C. R. Mueller (1988). Lactational response to soybean meal, heated soybean meal and extruded soybeans with ruminally protected methionine Journal of Dairy Science. 71: 173-180.

Shamoon, S. A.; M. N. Saleh; N. Y. Abbo (2009). Effects of different levels of protein treated with formaldehyde on nutrients digestibility and some rumen and blood parameters in Awassi sheep. Iraqi Journal of Veternary Science. 23: 169-173.

Small, J.; D. J. Gordon (1985). The effect of source of supplementary protein on performance of dairy cows offered grass silage as the basal diet. Journal of Animal Production. 40: 520 (Abstract).

Subnel, A. P. J.; R. G. Meijer; W. M. Van Stralen; S. Tamminga (1994). Effeciency of milk production in the DVE protein evaluation system. Journal of Livestock Production Science. 40: 215-224.

Toghdory, A.; T. Ghoorchi; A. Naserian; Y. J. Ahangary; S. Hassani (2009). Effect of rumen protected and unprotected choline on energy related biochemical 
metabolites of lactating dairy cows. Journal of Animal And Veternary Advances. 8(1): 2181-2185.

Wattiaux, M. A.; D. K. Combs; R. D. Shaver (1994). Lactational response to ruminally undegradable protein by dairy cows fed diets based on alfalfa silage. Journal of Dairy Science. 77: 1604-1607.

Wren, T. R.; J. R. Weyant; D. L. Wood; J. Bitman (1975). Increasing polyunsaturated of milk fats by feeding formaldehyde protected sunflower-soybean supplement. Journal of Animal Science.4: 59. 
Mesopotamia J. of Agric.

Vol. (45) No. (1) 2017
ISSN: 2224 - 9796 (Online)

ISSN: 1815 - 316 X (Print)

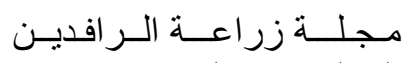

المجلد (45) العدد (1) 2017 